\title{
The Influence of Letter Card Play to The Recognition of Letters for Children Aged 5-6 Years In TK Salsa Percut Sei Tuan
}

\author{
Nasriah $^{1 *}$, Elya Siska Anggraini ${ }^{2}$, Roni Sinaga ${ }^{3}$, Tuty Alawiyah Nasution ${ }^{4}$ \\ ${ }^{1-4)}$ Faculty of Education, Universitas Negeri Medan, Indonesia \\ *nasriahcut@yahoo.co.id
}

\begin{abstract}
The purpose of this study was to determine the effect of letter cards on letter shape recognition in group B children at Salsa Percut Sei Tuan District Kindergarten. This research is a post test only control group design study. Class determination is carried out randomly with a total of one class for BI 27 children and BII 28 children, data analysis using a t-test. Based on data analysis obtained an average value in the experimental class 84.71 , the highest value 121 , the lowest value 49 , while the average value in the control class 48.51 , the highest value 100 , the lowest value 25 , so that the cognitive development of children in the control class obtained a significant difference ( $t$ count $>$ t-table was $5.487>1.688$ ). Thus it can be concluded that there is a significant effect of playing letter cards on the introduction of letter shapes in children aged 5-6 years in Salsa Percut Kindergarten, Sei Tuan District.
\end{abstract}

Keywords: Games, Letter Cards, Letter Forms

\section{Introduction}

Early childhood education is a process of fostering growth and development of children from birth to the age of six as a whole which includes aspects of physical and non-physical by providing stimulus for the development of physical, cognitive, language, social-emotional and religious values right so that children grow and develop optimally.

In its activities PAUD is education that carries out "learning while playing" activities, through playing children can carry out various activities that are useful for the development of all aspects of themselves. Through play children learn to observe measure, compare, explore, research, and much more that can be done by children. Situations like this are often done by children so that without realizing that the child has trained himself in developing several aspects of development, one of which is the aspect of cognitive development.

Based on the descriptions above to improve cognitive development to recognize the shape of the letters of the alphabet in early childhood can be stimulated by using the Educational Card Letter Educational Tools, the authors interested this research. The researcher identifies various problems that arise, namely The recognition of the letters of the alphabet in children aged 5-6 years is still low. The researchers limit the issues to be studied are "Influence Tool Game Card Recognition Letter Against Childhood Lettering In 5-6 Years Group.

Purpose of this study is to determine how much effect of tools games card letter toward introduction lettering in Children Ages 5-6 years. The introduction of the form of letters is one aspect that must be achieved by children in aspects of cognitive development. The 
introduction of alphabetical letters in early childhood is a child's ability to know and understand letter symbols in developing children's ability to think symbolically. According to Darjowidjojo [1] revealed that the ability to recognize letters is the stage of children's development from not knowing to knowing about the relationship of the shape and sound of letters, so that children can know the shape of letters and interpret them.

Recognizing letters is a basic ability that must be possessed by a child so that children can learn to know, and recognize various forms of letters. Because if the child can recognize the letters of the alphabet, it will be easier to say the shape of the letters. As quoted in Minister of Education and Culture Regulation of the Republic of Indonesia No 137 of 2014 concerning National Standards of Early Childhood Education, it is explained that the introduction of the form of letters in children aged 5-6 years can be seen in aspects of cognitive development that is in the scope of the development of symbolic thinking, and think logically.

Children who learn to recognize letters from an early age can benefit children. As for the benefits of learning from recognizing the shape of letters according to Carol [2] namely as a milestone in the kindergarten curriculum through repeated and meaningful disclosure to the events introduction to the concept of letters, so that children become aware of the letters and understand that the letters can form a word. Educational card game is a game that can stimulate the cognitive development of children in recognizing various forms of the alphabet. Letter card games are learning that uses letter cards to improve children's ability to recognize letter shapes. The child will know the shapes of the letters of the alphabet through the card game given by the teacher as stimulation in stimulating the cognitive development of children. Puzzle game is one of the play activities, and Rokhmat [3] states, puzzle is a game of construction through the activity of installing or pairing boxes, or pictures of certain shapes so that eventually they form a certain pattern.

\section{Research Method}

This research is an experimental research namely Posttetst-Only Control Group Design. With the following steps: 1) The researcher determines which experimental class and the control class by drawing lots using paper. The researcher inserted the paper with the BI and BII class names into an empty bottle and then shook it and the first paper that came out would be used as an experimental class, and the second paper would be used as the control class. 2) Determination of the treatment or treatment of the experimental class that is by doing game activities using the media of educational tools playing the letter cards in contrast to the control class that is by doing puzzle games drawing up pictures 3) Researchers discuss with the experimental class teacher and the teacher.

The childs who are used in this research are all kindergarten children in group B in Salsa Kindergarten with 55 children, namely B.1 27 children and B.2 28 children with characteristics of the same of age children 5-6 years of age. The selection of experimental groups is randomly assigned [4]. Data analysis using the comparative t-test with the formula:

$$
\mathrm{t}=\frac{X_{1}-X_{2}}{\sqrt[s]{\frac{s}{n 1}+\frac{s}{n 2}}}
$$

The hypothesis testing criteria is accept Ho if $t$ arithmetic $>t$ table and reject Ho if $t$ has other prices. 


\section{Results and Discussion}

Observation sheets have been arranged in such a way that they can be used to capture data on children's development in the introduction of alphabetic letters in the experimental and control classes. The lowest value is 4 , the highest value is 11 with an average of 8.857 and a standard deviation of 1.746. The results of observations of children's fine motor skills in the experimental class so it can be described in the form of a diagram as follows

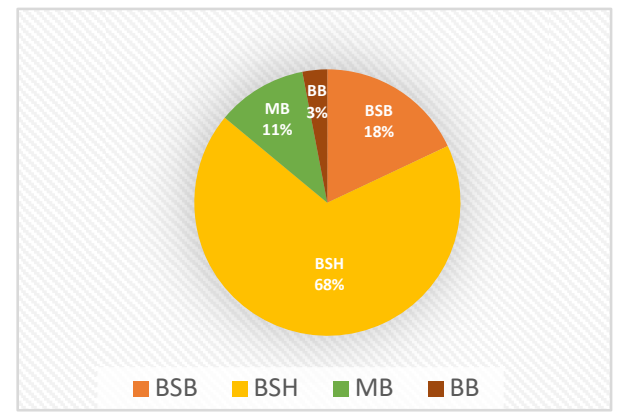

Picture 1. Data Recognition of Letter Shapes (Experimental Class)

Data distribution of control group about the observation results of letter recognition in children can be described in the form of a diagram as follows.

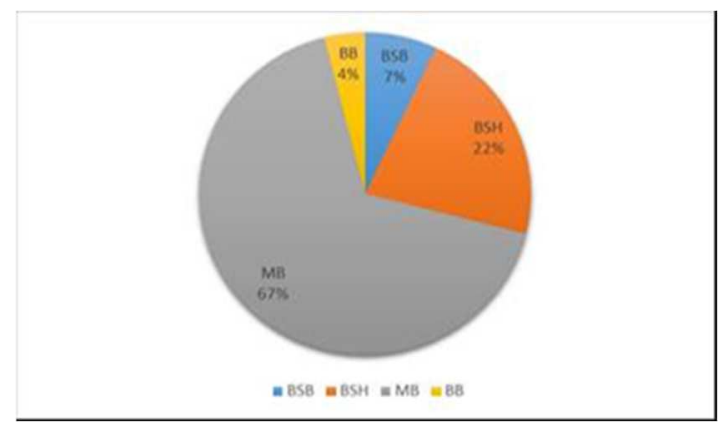

Picture 2. Data Recognition of Experimental Class

The Childs ability to recognize letter shapes on the MB score gets a value of $67 \% 18$ children, who get a BSH score get a value of $22 \% 6$ children, who get a BSB score get a $7 \%$ score 2 children who get a BB score get a value $4 \% 1$ child. In the process of obtaining the results of the analysis, before giving a different treatment to the sample class that is the experimental class and the control class there is no difference between the control class and the experimental class. However, after the different treatment given the experimental class and control class, there is a significant result of the influence of the letter cards to the introduction of the form letter in children aged 5-6 years, then the $\mathrm{t}$ test results obtained $\mathrm{H}_{0}$ is rejected and $\mathrm{H}_{\mathrm{a}}$ accepted. Based on the results of data analysis, obtained an average score in the introduction of letter shapes in the experimental class and the control class, with an average value of 9.07 experimental class children and the average value of children in the control class 6.81 From the final observation results the two samples obtained a difference of 2.25 from the 
data obtained there is a significant difference between the identification of letters in the experimental class and the control class. This is due to the use of the media of letter cards in introducing the shape of letters for children aged 5-6 years is very good because in the introduction of this form of letters children will be trained in stages starting from the easy to the difficult. This finding is of this research in line with theoretical studies and previous studies such as Rokhmat [3], Arsyad [5], Baharuddin [6], Rolina [7] and Suyanto [8].

\section{Conclusion}

Based on the results of research and data processing, results of observation of letter shape recognition in children in the experimental class have an average value of 9.07 greater than the results of observation of recognition of shape of letters in children in the control class which have an average value of 6,81 . So it can be concluded that there is an influence of letter card playing on letter shape recognition in children aged 5-6 years, in addition to being able to develop children's abilities in recognizing letter shapes, letter card games can also develop other aspects of development in children such as social development, cognitive, language and children's learning interest. So it can be declared significant effect on the game card letter to letter shape recognition in children aged 5-6 years.

\section{References}

[1] Dardjowidjojo, S. (2003), Introduction to Understanding Human Language. Jakarta: Indonesian Torch Foundation.

[2] Carol Seefeldt. (2008), Early Childhood Education Programs, Jakarta: Index.

[3] Rokhmat, J. (2006), Development of Game-Based Educational Parks for Learning in Kindergarten and Elementary School . Journal of Educational Dynamics, v.2.

[4] Sugiyono. Research Methods Quantitative, Qualitative, and R\&D Approaches, Bandung: Alfabeta, (2013).

[5] Arsyad, Azhar. (2005), Learning Media, Jakarta: Raja Grafindo Persada.

[6] Baharuddin. (2009), Educational and Developmental Psychology, Yogyakarta: Ar-Ruzz.

[7] Rolina Nelva. (2012), Educational Game Tools For AUD. Yogyakarta: Waves.

[8] Suyanto Slamet. (2005), Basics of Early Childhood Education. Yogyakarta: Hikayat Publishing. 